\title{
GCU
}

Glasgow Caledonian

University

University for the Common Good

\section{Determining fPAR and leaf area index of several land cover classes in the Pot River and Tsitsa River catchments of the Eastern Cape, South Africa}

Palmer, Anthony R.; Finca, Andiswa; Mantel, Sukhmani K.; Gwate, Onalenna; Munch, Zahn; Gibson, Lesley A.

Published in:

African Journal of Range and Forage Science

DOI:

$10.2989 / 10220119.2017 .1306582$

Publication date:

2017

Document Version

Author accepted manuscript

Link to publication in ResearchOnline

Citation for published version (Harvard):

Palmer, AR, Finca, A, Mantel, SK, Gwate, O, Munch, Z \& Gibson, LA 2017, 'Determining fPAR and leaf area index of several land cover classes in the Pot River and Tsitsa River catchments of the Eastern Cape, South Africa', African Journal of Range and Forage Science, vol. 34, no. 1, pp. 33-37.

https://doi.org/10.2989/10220119.2017.1306582

\section{General rights}

Copyright and moral rights for the publications made accessible in the public portal are retained by the authors and/or other copyright owners and it is a condition of accessing publications that users recognise and abide by the legal requirements associated with these rights.

Take down policy

If you believe that this document breaches copyright please view our takedown policy at https://edshare.gcu.ac.uk/id/eprint/5179 for details

of how to contact us. 


\title{
Determining fPAR and LAI (leaf area index) of several land cover classes in portion of the Great Kei and Tsitsa River Catchments, north Eastern Cape, South Africa.
}

\author{
Anthony R. Palmer ${ }^{\mathrm{ab}}$, Onalenna Gwate ${ }^{\mathrm{b}},{\text { Zahn } \text { Munch }^{\mathrm{c}} \text {, Perpetua Okuye }}^{\mathrm{c}}$, Lesley Gibson ${ }^{\mathrm{d}}$, \\ Andiswa Finca $^{\mathrm{a}}$ and Sukhmani Mantel ${ }^{\mathrm{b}}$ \\ a Agricultural Research Council-Animal Production Institute, PO Box 101, Grahamstown, 6140, \\ South Africa \\ ${ }^{\mathrm{b}}$ Institute for Water Research, Rhodes University, Grahamstown, South Africa \\ ${ }^{c}$ Department of Geography, University of Stellenbosch, Stellenbosch, South Africa. \\ ${ }^{\mathrm{d}}$ Glasgow Caledonian University, United Kingdom.
}




\begin{abstract}
Determining the quantum (both annual maxima and minima) and the temporal variation in the leaf area index (LAI), and the fraction of photosynthetically active radiation (fPAR), are three fundamental biophysical characteristics of the plant canopy that should parameterize ecophysiological models of water use (evapotranspiration) and carbon sequestration. Although earth observation provides values and time series for both these parameters, in-field validation of these values is necessary. Following a very wet summer season, we conducted field surveys of several land cover classes within two quaternary catchments in the Eastern Cape province, South Africa, to determine maximum values of LAI and FPR that occur within each of these land cover classes. To assist in up-scaling these point measures to the landscape, we present a regression relationship between Landsat 8 NDVI and leaf area index measured using an Accupar Ceptometer $(\mathrm{r} 2=0.92)$. Peak wet season LAI varied from extremely high $(>7.0)$ under the canopy of invasive black wattle (Acacia mearnsii) trees to $\sim 2.0$ under the canopy of a Eucalyptus plantation. Un-grazed native grassland displayed an intermediate LAI value of 3.84. The black wattle stand absorbed $97 \%$ of the available PAR, where the mature Eucalyptus plantation only absorbed $66 \%$ of PAR.
\end{abstract}


The compliance and reporting requirements for several international conventions, such as the Clean Development Mechanism and REDD+, make it imperative that governments prepare themselves for quantifying and validating estimates of net ecosystem carbon exchange (NEE). The NEE represents the resultant sum of all the carbon captured in the process of photosynthesis minus that released through respiration from the plants and the soil surface (Shi et al. 2014). The storage of carbon by each ecosystem component is driven by several biophysical parameters associated with each land cover unit, including the structure and physical characteristics of the plant canopy, the energy (including but not limited to air temperature, soil heat and net solar radiation), water relations, and the amount and season of rainfall) experienced by that land unit. In water limited regions such as South Africa, negotiations around water licensing require evidenced-based estimates of the water-use of each land cover type within a catchment. Part of this process is to establish total annual evapotranspiration (ET) associated with each land cover class within a catchment. In order to contribute towards an improved understanding of the carbon-water nexus described above, we have measured several key variables that are used in models of NEE and ET in South African mixed farming landscapes.

Recently, significant advances have been made in modelling NEE using Earth observation/remote sensing (Xiao et al. 2008). Photosynthetically active radiation (PAR) is the solar radiation in the visible part of the spectrum in the interval of 400-700 $\mathrm{nm}$ that is available to drive photosynthesis. It is a crucial component of the light use efficiency model of primary production. It has been recommended that a standard definition of the light use efficiency (LUE) model should be based exclusively on radiation absorbed by green vegetation (Gitelson \& Gamon 2015). In situ measurements of the fraction of PAR (fPAR) that is absorbed by the plant canopy are necessary if we are to validate production models developed from remotely sensed data.

Leaf area index (LAI) is a dimensionless variable, described as the maximal projected leaf area per unit ground surface area (Myneni et al. 1997). LAI is a fundamental biophysical parameter through which canopy physiological functioning can be related to indices derived from Earth observation using satellite-borne sensors, especially the normalized difference vegetation index (NDVI)(Pettorelli et al. 2005). Canopy LAI can be highly correlated with fPAR, net primary 
productivity (NPP) and biosphere-atmosphere exchange of heat, momentum and many important trace gases (Ref?). LAI can also be integrated into the Penman-Monteith equation to predict actual evapotranspiration (Leuning et al. 2009; Palmer et al. 2015). The LAI of vegetation is spatially and temporally highly variable and depends on species composition, development stage, seasonality and the prevailing site conditions (water supply and soil fertility) and management practices (Le Dantec et al. 2000). LAI and fPAR characterize canopy function and energy absorption capacity and they are key parameters in most ecosystem productivity models and global models of climate, hydrology, biogeochemistry and ecology (Sellers et al. 1997).

There is a strong call to the effective measurement of the water and carbon fluxes above different categories of land-use (Foley et al. 2005) as each has a different capacity to accumulate or utilize above- and below-ground biomass. The clarion call for carbon accumulation in soils and above ground standing biomass to combat increasing trends in atmospheric $\mathrm{CO}_{2}$ concentration has meant that models of $\mathrm{C}$ assimilation and water use are legion. Biomass accumulation is determined by assimilation activity and allocation of assimilates, but there are biophysical limits to an ecosystem's ability to continue assimilating $\mathrm{CO}_{2}$. These processes are affected by the climatic conditions of the local environment, but also by the land management activities associated with human occupation. The assimilation activity is strongly dependent on the accessibility of solar radiation and its absorption plays a key role in a set of physical processes connected to stand biomass production (Markova et al. 2011). Light and temperature are probably the most important variables affecting leaf growth. Generally, as the leaf ages, photosynthetic capacity initially increases, reaches a maximum soon after it is fully expanded, and then declines (Woledge \& Parsons 1986). The decline starts before any visible signs of senescence (Woledge \& Parsons 1986) are obvious. Thus, the amount of the absorbed solar radiation during the growing season determines biomass production (Linder 1985).

The production of stand biomass at a particular locality is determined not only by the absorbed solar radiation but also by the efficiency of conversion of this radiation energy into biomass (significantly determined by the stand structure) and the "quality" of the locality e.g. water and nutrition availability (Xu et al. 2006). Monteith \& Moss (1977) reported a linear relationship between PAR, which is absorbed by the stand and aboveground dry-matter production over 
relatively short time spans (i.e. days of the growing season). The linear character of this relationship is a great advantage and many empirical studies have supported this assumption (Madakadze et al. 1998). The final amount of PAR absorbed by the given stand structure results from the amount of incident solar radiation, effectiveness of leaf absorbed PAR and/or the considered time period (length of the growing season). Increased incident PAR escalates the potential amount of absorbed PAR (Stenberg et al. 1994; Oker-Blom et al. 1989). The duration of PAR absorption by active leaf area affects the final biomass formation and thus the differences between individual seasons are obvious. The growth of the biomass responsible for PAR will be dependent on the efficiency of the assimilate conversion into biomass and biomass allocation.

The rate of plant growth, and production of forage, depends on the size of the photosynthetic (leaf) area available for trapping sunlight and the efficiency with which this leaf area can photosynthesize. These two aspects are closely related since leaf expansion is dependent on the availability of energy substrates, which is in turn related to photosynthetic rate. In practice, however, leaf expansion and photosynthetic rate may respond to changing circumstances. This paper provides data on field validation of fPAR and LAI for selected land cover classes in two catchments with contrasting land tenure arrangements, with a specific focus on the use of this information for establishing the fPAR and LAI values for use in catchment scale hydrological and evapotranspiration models.

We surveyed two quaternary catchments (S50E and T35B) in the Great Kei and Tsitsa River Primary catchments. Both catchments are representative of areas where invasive alien plants (IAPs) are a threat to un-improved grasslands. These quaternary catchments contain a range of land cover types including commercial forestry, commercial dryland cultivation (maize and soya beans), native forests, IAPs, wetlands, urban areas and un-improved grasslands (Table 1). Quaternary catchment S50E, near Cala, supplies the Ncora dam on the Tsomo River. The Ncora dam was completed in 1975 , with a capacity of $150 \times 10^{6} \mathrm{~m}^{3}$ and a surface area of 1392 ha. There is no large dam in quaternary catchment T35B. In S50E, the leasehold land tenure system has encouraged mixed communal settlements comprising traditional village dwellings, dryland cultivation and rangeland. In $\mathrm{T} 35 \mathrm{~B}$, the land tenure is predominantly freehold, and land cover 
comprises extensive dryland cultivation, commercial afforestation and extensive un-improved grassland for livestock production. Both catchments have experienced extensive IAP invasion by three important aggressive taxa, namely black wattle (Acacia mearnsii), silver wattle (Acacia dealbata) and poplar (Populus spp), with IAP clearing operations having been initiated by the Working for Water (WfW) programme of the South African Department of Environment Affairs.

The LAI of a sub-sample of nine sites was measured using an AccuPAR Ceptometer model LP80 PAR/LAI (Decagon Devices Inc., Pullman, Washington USA). The ceptometer makes use of changes in photosynthetically active radiation (PAR) to determine LAI (Butterfield \& Malmstrom 2009). Along the wand of the ceptometer there are eighty $1 \mathrm{~cm}^{2}$ sensors that determine the PAR of the selected canopy, and these measurements are integrated into a single value of LAI using the inversion method. During a field campaign in January 2014, we measured LAI and fPAR at selected examples of nine land cover classes and examples of areas invaded by IAPs (Table 1). This is regarded as the peak of the growing season in this region, and Maclear had received $350 \mathrm{~mm}$ of rainfall in the preceding 120 days. At each site, repeated (ten) recordings of LAI and fPAR were recorded on cloudless days between $11 \mathrm{~h} 00$ and $13 \mathrm{~h} 00$. All the readings for each land cover class encountered in the study area were used to calculate a mean fPAR and LAI per cover class, and to provide full descriptive statistics that can be used in NEE and ET models.

A Landsat 8 image of the study area was acquired for 16 January 2014 (within 7 days of the field survey), radiometrically and geometrically corrected using Open-Source GRASS GIS image processing software (Version 7.0.5RC2)( https://grass.osgeo.org), and a normalized difference vegetation index was prepared. Using the geo-location information for each land cover class, a mean NDVI for each cover class was extracted using a 20-pixel sampling window. These measured fPAR and LAI values for samples from several land cover types, plantations and crops are the first reported from in-field measurements for sites in these catchments (Figures 1 and 2). The highest mean LAI value $(\mathrm{x}=7.38)$ for the entire study area was recorded under a monospecific plantation of black wattle in the riparian zone, adjacent to a village on communal land (Table 2 ). The $2^{\text {nd }}$ highest LAI occurred in an actively growing stand of black wattle upon a rocky slope on former commercial rangeland. The mature eucalyptus plantation had the lowest LAI and fPAR when compared to all other cover types at the peak of the growing season. Native 
grassland and immature pine plantation both had lower LAI and fPAR values than the other selected examples of land cover.

There was a significant, positive correlation between the field-measured LAI and the NDVI from the Landsat 8 image of 16 January 2014 (Figure 3)(F-value $=38.57, p<0.001$ ). The proportion of land surface that each cover class occupies in the two quaternary catchments in this study shows that native forest and IAPs together currently occupy $12.4 \%$ (T35B) and $10.8 \%$ (S50E) of quaternary catchment area (Munch et al. 2017).

The results indicate that there are extremely high LAI values associated with stands of mature black wattle, and suggest that these IAPs are significant users of water in these landscapes relative to all other land cover classes. The contribution of these IAPs to catchment-scale water use needs to be determined after a more comprehensive study of the area occupied by each land cover class. Preliminary results of the proportion of land surface that each cover class occupies in the two quaternary catchments suggest that the total contribution of IAPs to the catchment-scale water balance may not be as high as anticipated. The strong positive relationship between the infield measurements of LAI and the Landsat 8 NDVI indicates that it will be possible to apply the results of the in-field validation of LAI to the entire catchment. As LAI is a significant input into the algorithms used to model catchment evapotranspiration, this result will improve catchmentscale estimates of ET. The fraction of PAR intercepted by all the plant canopies was greater than 0.9 in all but three of the land cover classes (Table 2). This indicates that in-field measurements were recorded when active growth was at or close to maximum thereby providing maximum possible values for LAI, fPAR and ET for each of these cover classes. These maximum values are crucial in parameterizing models for NEE and ET (Palmer et al. 2015).

\section{Acknowledgements}

The research was funded by Water Research Commission Project K5/2400/4

\section{References}

Butterfield H \& Malmstrom C 2009 The effects of phenology on indirect measures of aboveground biomass in annual grasses. International Journal of Remote Sensing $303133-$ 3146.

Le Dantec V, Dufrene E \& Saugier B 2000 Inter-annual and Spatial variation in Maximum Leaf 
Area Index of Temperate Deciduous Stands. Forest Ecology and Management 134 71-81.

Foley JA, Defries R, Asner GP, Barford C, Bonan G, Carpenter SR, Chapin FS, Coe MT, Daily GC, Gibbs HK et al. 2005 Global consequences of land use. Science (New York, N.Y.) 309 $570-574$.

Gitelson AA \& Gamon JA 2015 The need for a common basis for defining light-use efficiency: Implications for productivity estimation. Remote Sensing of Environment 156 196-201.

Leuning R, Zhang YQ, Rajaud A, Cleugh H \& Tu K 2009 A simple surface conductance model to estimate regional evaporation using MODIS leaf area index and the Penman-Monteith equation (vol 45, W10419, 2008). Water Resources Research 45.

Linder S 1985 Potential and actual production in Australian forest stands. In Research Forest Management, pp 11-35. Eds J Landsberg \& W Parsons. Melbourne, Australia: CSIRO.

Madakadze IC, Coulman BE, Peterson P, Stewart KA, Samson R \& Smith DL 1998 Leaf area development, light interception, and yield among switchgrass populations in a short-season area. Crop Science 38 827-834.

Markova I, Pokorny R \& Marek M 2011 Transformation of solar radiation in Norway spruce stands into produced biomass-the effect of stand density. Journal of Forest Science. $\mathbf{5 7}$ $233-241$.

Monteith JL \& Moss CJ 1977 Climate and the Efficiency of Crop Production in Britain [and Discussion]. Philosophical Transactions of the Royal Society B: Biological Sciences 281 277-294.

Munch Z, Okoye PI, Gibson LA, Mantel SK \& Palmer AR 2017 Characterizing degradation gradients through land cover change analysis in rural Eastern Cape, South Africa. Geosciences 7.

Myneni RB, Nemani RR \& Running SW 1997 Estimation of global leaf area index and absorbed par using radiative transfer models. IEEE Transactions on Geoscience and Remote Sensing 35 1380-1393.

Oker-Blom P, Pukkala T \& Kuuluvainen T 1989 Relationship between radiation interception and photosynthesis in forest canopies: effect of stand structure and latitude. Ecological Modelling 49 73-87.

Palmer AR, Weideman C, Finca A, Everson CS, Hanan N \& Ellery W 2015 Modelling annual evapotranspiration in a semi-arid, African savanna: functional convergence theory, MODIS LAI and the Penman-Monteith equation. African Journal of Range \& Forage Science 32 $33-39$.

Pettorelli N, Vik JO, Mysterud A, Gaillard JM, Tucker CJ \& Stenseth NC 2005 Using the satellite-derived NDVI to assess ecological responses to environmental change. Trends in Ecology \& Evolution 20 503-510.

Sellers P, Randall D, Betts A, Hall F, Berry J, Collatz G, Denning A, Mooney H, Nobre C, Sato $\mathrm{N}$ et al. 1997 Modelling the exchanges of energy, water and carbon between continents and the atmosphere. Science 275 502-509. 
Shi H, Li L, Eamus D, Cleverly J, Huete A, Beringer J, Yu Q, van Gorsel E \& Hutley L 2014 Intrinsic climate dependency of ecosystem light and water-use-efficiencies across Australian biomes. Environmental Research Letters 9104002.

Stenberg P, Kuuluvainen T \& Kellomäki S 1994 Crown structure, light interception and productivity of pine trees and stands. Ecological Bulletins 20-34.

Woledge J \& Parsons A 1986 Temperate grasslands. In Photosynthesis in Contrasting Environments. Eds N Baker \& S Long. Amsterdam: Elsevier.

Xiao JF, Zhuang QL, Baldocchi DD, Law BE, Richardson AD, Chen JQ, Oren R, Starr G, Noormets A, Ma SY et al. 2008 Estimation of net ecosystem carbon exchange for the conterminous United States by combining MODIS and AmeriFlux data. Agricultural and Forest Meteorology 148 1827-1847.

Xu CY, Gong LB, Tong J \& Chen DL 2006 Decreasing reference evapotranspiration in a warming climate - A case of Changjiang (Yangtze) River catchment during 1970-2000. Advances in Atmospheric Sciences 23 513-520.

List of figures and tables

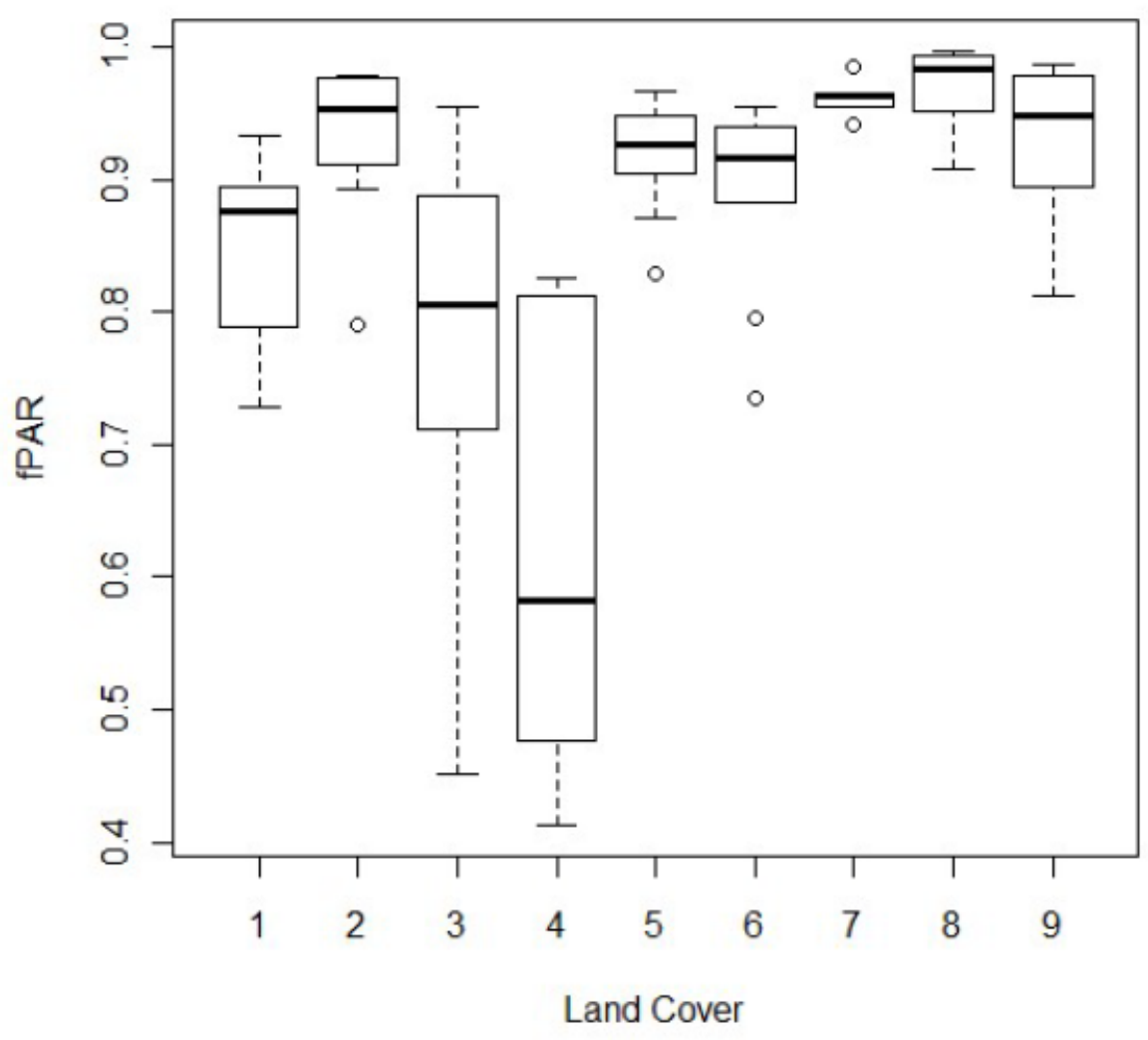

Figure 1. Boxplots of fPAR values for grassland (1) old pine plantation (2) young pine plantation (3) mature gum (4) wetland (5) mature maize field (6) wattle on rocky soils (7) wattle in riparian zone (8) and mixed wattle and gum in riparian zone (9). Boxplots 
provide the median (dark line), upper and lower quartiles (box), mean (mid-point of the box) and extremes of the data set.

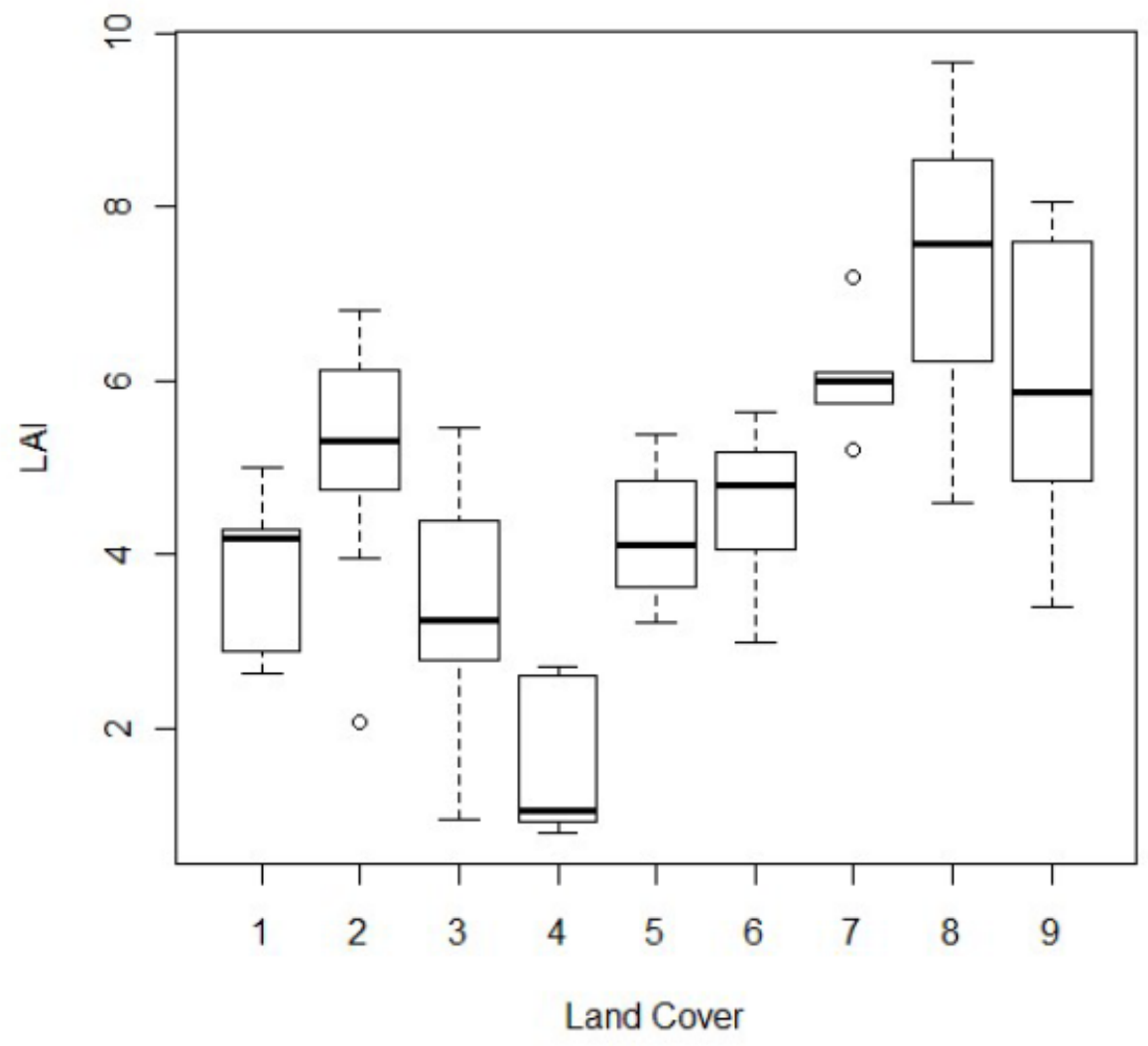

Figure 2. Boxplots of LAI values for grassland (1) old pine plantation (2) young pine plantation (3) mature gum (4) wetland (5) mature maize field (6) wattle on shallow rocky soils on slope (7) wattle in riparian zone (8) and mixed wattle and gum in riparian zone (9). 


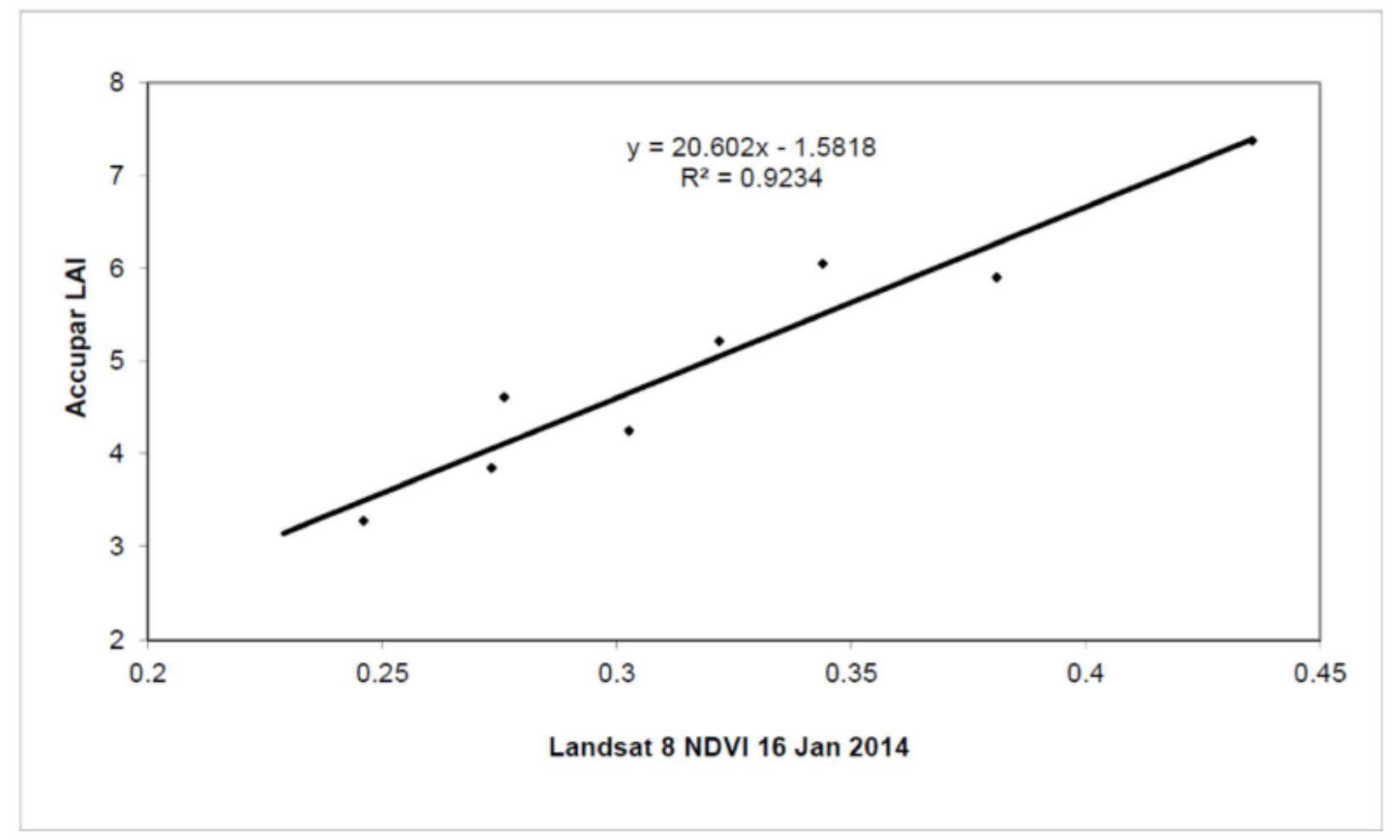

Figure 3. The relationship between field measured LAI and the NDVI (normalized difference vegetation index) values extracted from a Landsat 8 for 16 January 2014 for each of the cover classes.

Table 1. The changes in the area of the dominant land cover classes within the two quaternary catchments between 2000 and 2015 (Munch et al. in press).

Table 1. Comparison of the changes in land cover class areas for the two quaternary catchments between 2000 and 2014. Significant change in values (either decrease or increase) is indicated in bold.

\begin{tabular}{|c|c|c|c|c|c|c|c|c|c|}
\hline & \multicolumn{4}{|c|}{ QC T35B } & \multicolumn{5}{|c|}{ QC S50E } \\
\hline & 2000 & & 2014 & & 2000 & & 2014 & & \\
\hline & $\begin{array}{l}\text { Area } \\
\left(\mathbf{k m}^{2}\right)\end{array}$ & $\%$ & $\begin{array}{l}\text { Area } \\
\left(\mathbf{k m}^{2}\right)\end{array}$ & $\%$ & $\begin{array}{l}\text { Area } \\
\left(\mathbf{k m}^{2}\right)\end{array}$ & $\%$ & $\begin{array}{l}\text { Area } \\
\left(\mathbf{k m}^{2}\right)\end{array}$ & & $\%$ \\
\hline $\begin{array}{l}\text { Un-improved } \\
\text { Grassland }\end{array}$ & 315 & 79.6 & 316 & 79.8 & 343.6 & 76.8 & & 253.5 & 56.6 \\
\hline $\begin{array}{l}\text { Forest (native \& } \\
\text { IAPs) }\end{array}$ & 48 & 12.3 & 16.3 & 4.1 & 23.9 & 5.3 & & 48.1 & 10.8 \\
\hline Bare Rock \& Soil & .1 & $\sim 0.0$ & 0.8 & 0.2 & 142 & 0.3 & & 0.96 & 0.2 \\
\hline Waterbody & .1 & $\sim 0.0$ & 0.2 & 0.0 & 15.7 & 3.5 & & 13.0 & 2.9 \\
\hline Wetland & 7.7 & 2.0 & 4.7 & 1.2 & 1.1 & 0.2 & & 0.59 & 0.1 \\
\hline Cultivated & 11.6 & 2.9 & 24.4 & 6.2 & 20.9 & 4.7 & & 81.0 & 18.1 \\
\hline Forest Plantation & 11.5 & 2.9 & 32.7 & 8.3 & 17.2 & 3.8 & & 8.1 & 1.8 \\
\hline
\end{tabular}


Table 2. The mean LAI and PPAR values for each of the major land cover classes found in the study area.

Table 2. The mean LAI and fPAR values for each of the major land cover classes found in the study area.

\begin{tabular}{|r|l|r|r|}
\hline $\begin{array}{l}\text { Cover } \\
\text { type } \\
\text { number }\end{array}$ & Land cover class & $\begin{array}{l}\text { Mean } \\
\text { LAI }\end{array}$ & $\begin{array}{l}\text { Mean } \\
\text { fPAR }\end{array}$ \\
\hline 1 & Native grassland & 3.84 & $\mathbf{0 . 8 4}$ \\
\hline 2 & Mature pine plantation (>15 years) & 5.21 & $\mathbf{0 . 9 4}$ \\
\hline 3 & Immature pine plantation (<3 years) & $\mathbf{3 . 2 7}$ & $\mathbf{0 . 7 8}$ \\
\hline 4 & Mature Eucalyptus plantation & $\mathbf{2 . 0 9}$ & $\mathbf{0 . 6 6}$ \\
\hline 5 & Native wetland & $\mathbf{4 . 2 5}$ & $\mathbf{0 . 9 2}$ \\
\hline 6 & Mature maize (commercial dryland) & $\mathbf{4 . 6 1}$ & $\mathbf{0 . 8 9}$ \\
\hline 7 & Black wattle on shallow rocky soils on slope & $\mathbf{6 . 0 5}$ & $\mathbf{0 . 9 6}$ \\
\hline 8 & Black wattle in riparian zone & 7.38 & $\mathbf{0 . 9 7}$ \\
\hline 9 & Mixed black wattle and gum in riparian zone & $\mathbf{5 . 9 0}$ & $\mathbf{0 . 9 3}$ \\
\hline
\end{tabular}

